\section{SCIENCE AND THE UNITED NATIONS}

\section{$\mathrm{T}$}

WHE Conference on "Scientists of the United Nations and the War Effort" convened by the Association of Scientific Workers on December 5-6 covered a very wide field. Men of science must leave no doubt about their attitude to the ideologies and practices of the Nazis and Fascists. There is no question about the importance attached to science by the Nazis. Dr. Kuczynski, the famous statistician, speaking of Germany, told of the prestige there enjoyed by men of science. Speakers from Norway, Belgium and Denmark spoke of the attempts of the Nazis to impose their ideology through the universities and schools. These speakers and a Greek man of science, whose name was not published, also told of the resistance which the staffs of universities and schools are making. In Norway, for example, the universities have refised to do anything that was not legal before the invasion; the school teachers have resisted Nazi orders although one in five has been sent to a concentration camp.

The Norwegians had to face a clear-cut issue and made their choice; in Germany, as Dr. Kuczynski related, many men of science were not deliberate supporters of the Nazi regime; but, because they hoped to continue their work without interfering in public affairs, they have become active assistants of the Nazis. This leads to a point made by Dr. G. Lewi, formerly secretary-general of the Federation of Czechoslovak Chemical Industries, deputy chairman of the Association of Czechoslovak Scientists and Technicians in Great Britain, who said that men of science, on whose work the whole structure of modern civilization is built, may not remain aloof from running that civilization. If they do, they will compromise with evil and find themselves committed to the wrong side.

The part played by the people of the occupied countries in the development of science was stressed by many of the speakers. Austria, as Dr. Stock pointed out, has produced six winners of Nobel prizes for science- one per million of population; the three living prize-winners left the country after the Anschluss. Mr. Pevtich, press attaché of the Yugoslav Embassy, told of the numerous Yugoslavs who have made conspicuous contributions to science. Dr. Frankenstein, professor of international law at The Hague, spoke of the debt which German science owes to Jews, of the valuable contributions to the Allied cause by Jews in Palestine in making instruments of precision and of the chemical work of Dr. Weissman, the Zionist leader. During the civil war in Spain the encouragement given to science by the Republicans had borne fruit in the development of an extensive blood transfusion service, the first of its kind, and a new method of treating wounds. In China the growth of science has been checked by the Japanese invasion, but continues and has been concentrated mainly on problems, such as those of nutrition and agriculture, that will be involved in reconstruction.

In the selection of a person for any position, two criteria only should be considered: he should be whole-heartedly opposed to Nazism and Fascism, and he should be the best qualified to do the work involved. In a time of total war we cannot take irrelevant matters such as nationality into account. Prof. Cassin, legal advisor to General de Gaulle, was able to claim that all men of science among the
Fighting French, both in Great Britain and the United States, are able to play their part to the full in the common struggle. - Miss Simpson, secretary of the Society for the Protection of Science and Learning, told of the work that the Society has done, first in finding positions for refugees and later in securing the release of men of science who were interned in Great Britain ; only twelve out of 526 appeals for release have been refused. Mr. T. H. Brind, of the International Labour Branch of the Ministry of Labour and National Service, spoke of the efforts made by his branch to overcome the difficulties that arise in getting full employment for alien scientific workers. However, several speakers expressed the view that adjustment is not complete. Even if no obstacles are raised by any Government Department there remains the prejudice of individual employers, which is likely to persist so long as the most ardent opponents of Nazism are labelled "enemy aliens". If the services of distinguished men of science are not used, agitation can be made and the matter is put right. But there is no machinery for redress in such a case as that of a young man who had served with the Pioneers in France, had distinguished himself in a course of training in making instruments of precision, but was then not employed on the work to which he had been trained; for fear of military discipline, he cannot let his name be used. Also, until the men of science who supported the Spanish Republic and are now in North Africa are freed, we are not using all the scientific personnel at our disposal.

Prof. S. Chapman discussed the use of scientific personnel in the War. He suggested that there is a danger of overlapping of work and that this might be avoided if a central directory be set up from which a responsible person could learn whether any question which he proposed to study was already under investigation.

At the end of the Conference the following resolution was passed :

"We, scientific workers from countries menaced or oppressed by Nazi-Germany and her Allies, assembled in London in a conference, have resolved on the following.

"We accuse Germany and her Allies of systematically destroying the scientific institutions and exterminating the scientists of the occupied countries, as an integral part of her warfare, with the intention of strangling the scientific life and culture of those countries.

"We pledge ourselves to give our best in the fight against such monstrous barbarism, and to answer to-day each new crime with a further intensification of our efforts on behalf of the suffering peoples of the world by striking harder against these enemies of mankind.

"We appeal to our colleagues on the Continént and throughout the world to increase their efforts of which we hear again and again with emotion and pride against the oppressors. Only deeds count to-day and this applies equally to the freedom loving scientists on the Continent and to ourselves.

"We warn those who to-day willingly work for our oppressors that retribution is near.

"We express our satisfaction that a very con. siderable number of foreign scientific workers have already found work in this country which enables them to use all their knowledge and training in the common war effort, and hope that soon all of us will have found a place where the best use can be made of our experience and willingness to serve. 


\section{SCIENCE AND THE UNITED NATIONS}

\section{$\mathrm{T}$}

WHE Conference on "Scientists of the United Nations and the War Effort" convened by the Association of Scientific Workers on December 5-6 covered a very wide field. Men of science must leave no doubt about their attitude to the ideologies and practices of the Nazis and Fascists. There is no question about the importance attached to science by the Nazis. Dr. Kuczynski, the famous statistician, speaking of Germany, told of the prestige there enjoyed by men of science. Speakers from Norway, Belgium and Denmark spoke of the attempts of the Nazis to impose their ideology through the universities and schools. These speakers and a Greek man of science, whose name was not published, also told of the resistance which the staffs of universities and schools are making. In Norway, for example, the universities have refised to do anything that was not legal before the invasion; the school teachers have resisted Nazi orders although one in five has been sent to a concentration camp.

The Norwegians had to face a clear-cut issue and made their choice; in Germany, as Dr. Kuczynski related, many men of science were not deliberate supporters of the Nazi regime; but, because they hoped to continue their work without interfering in public affairs, they have become active assistants of the Nazis. This leads to a point made by Dr. G. Lewi, formerly secretary-general of the Federation of Czechoslovak Chemical Industries, deputy chairman of the Association of Czechoslovak Scientists and Technicians in Great Britain, who said that men of science, on whose work the whole structure of modern civilization is built, may not remain aloof from running that civilization. If they do, they will compromise with evil and find themselves committed to the wrong side.

The part played by the people of the occupied countries in the development of science was stressed by many of the speakers. Austria, as Dr. Stock pointed out, has produced six winners of Nobel prizes for science- one per million of population; the three living prize-winners left the country after the Anschluss. Mr. Pevtich, press attaché of the Yugoslav Embassy, told of the numerous Yugoslavs who have made conspicuous contributions to science. Dr. Frankenstein, professor of international law at The Hague, spoke of the debt which German science owes to Jews, of the valuable contributions to the Allied cause by Jews in Palestine in making instruments of precision and of the chemical work of Dr. Weissman, the Zionist leader. During the civil war in Spain the encouragement given to science by the Republicans had borne fruit in the development of an extensive blood transfusion service, the first of its kind, and a new method of treating wounds. In China the growth of science has been checked by the Japanese invasion, but continues and has been concentrated mainly on problems, such as those of nutrition and agriculture, that will be involved in reconstruction.

In the selection of a person for any position, two criteria only should be considered: he should be whole-heartedly opposed to Nazism and Fascism, and he should be the best qualified to do the work involved. In a time of total war we cannot take irrelevant matters such as nationality into account. Prof. Cassin, legal advisor to General de Gaulle, was able to claim that all men of science among the
Fighting French, both in Great Britain and the United States, are able to play their part to the full in the common struggle. - Miss Simpson, secretary of the Society for the Protection of Science and Learning, told of the work that the Society has done, first in finding positions for refugees and later in securing the release of men of science who were interned in Great Britain ; only twelve out of 526 appeals for release have been refused. Mr. T. H. Brind, of the International Labour Branch of the Ministry of Labour and National Service, spoke of the efforts made by his branch to overcome the difficulties that arise in getting full employment for alien scientific workers. However, several speakers expressed the view that adjustment is not complete. Even if no obstacles are raised by any Government Department there remains the prejudice of individual employers, which is likely to persist so long as the most ardent opponents of Nazism are labelled "enemy aliens". If the services of distinguished men of science are not used, agitation can be made and the matter is put right. But there is no machinery for redress in such a case as that of a young man who had served with the Pioneers in France, had distinguished himself in a course of training in making instruments of precision, but was then not employed on the work to which he had been trained; for fear of military discipline, he cannot let his name be used. Also, until the men of science who supported the Spanish Republic and are now in North Africa are freed, we are not using all the scientific personnel at our disposal.

Prof. S. Chapman discussed the use of scientific personnel in the War. He suggested that there is a danger of overlapping of work and that this might be avoided if a central directory be set up from which a responsible person could learn whether any question which he proposed to study was already under investigation.

At the end of the Conference the following resolution was passed :

"We, scientific workers from countries menaced or oppressed by Nazi-Germany and her Allies, assembled in London in a conference, have resolved on the following.

"We accuse Germany and her Allies of systematically destroying the scientific institutions and exterminating the scientists of the occupied countries, as an integral part of her warfare, with the intention of strangling the scientific life and culture of those countries.

"We pledge ourselves to give our best in the fight against such monstrous barbarism, and to answer to-day each new crime with a further intensification of our efforts on behalf of the suffering peoples of the world by striking harder against these enemies of mankind.

"We appeal to our colleagues on the Continént and throughout the world to increase their efforts of which we hear again and again with emotion and pride against the oppressors. Only deeds count to-day and this applies equally to the freedom loving scientists on the Continent and to ourselves.

"We warn those who to-day willingly work for our oppressors that retribution is near.

"We express our satisfaction that a very con. siderable number of foreign scientific workers have already found work in this country which enables them to use all their knowledge and training in the common war effort, and hope that soon all of us will have found a place where the best use can be made of our experience and willingness to serve. 
"We shall work to ensure that the co-operation among the scientists of so many countries which is developing to-day shall be a model for the integration of the world scientific effort after victory has been won."

\section{NEWTONIANISM AND SCHOLASTICISM}

IN his presidential address to the annual statutory meeting of the Royal Society of Edinburgh, under the title "Aristotle, Newton, Einstein", Prof. E. T. Whittaker compared the modern revolution in physics, by which the ideas of relativity and the quantum theory have displaced those of Newtonian mechanics, with the revolution in the seventeenth century when Newtonian mechanics triumphed at the expense of Aristotelian Scholasticism. His main thesis was that the Scholastic ideas which were destroyed by the movement of which the work of Newton marked the culmination, were a perverted form of the true philosophy of Aristotle, and that the modern outlook represents a return-or at least a tendency to return--to the true Aristotelian outlook. The work of Tycho and Kepler disproved and overthrew the existing Scholastic cosmology, but it contained nothing inherently irreconcilable with the Scholastic metaphysies and might conceivably have been absorbed into the philosophy of the Schoolmen by a peaceful and conservative revolution. Actually, however, what was essentially a new metaphysic was introduced. The basic postulate of the Newtonian mechanics, in which it differed sharply from Scholasticism, was the fundamental and independent status accorded to space and time. Persistence of bodies in time and their displacement in space became the concepts to which everything in the external world had to be reduced, and bodies moved in obedience to the forces which acted on them in space and time.

A partial return to the Aristotelian view that all change is a transition between a state which is potential and a state which is actual came with the doctrine of the conservation of energy, in which force is ignored and a change is represented by a transition between potential and other forms of energy ; and this tendency has more recently been emphasized by the quantum mechanics, in which the operator corresponding to classical potential energy is closely skin to the Aristotelian concept of potency. The introduction of 'minimum' principles, which culminated in 1915 when Hilbert introduced a 'world function' which determines all physical events in the universe by the condition that its integral taken over the whole of space-time is a minimum, marked another drift back to Aristotelianism, since such principles, like Aristotle's, are essentially teleological. General relativity, according to which gravitation represents a continual effort of the universe to straighten itself out, is so completely teleological that it would certainly have delighted the hearts of the Schoolmen. A free particle, in relativity theory, moves in a path determined solely by the curvatureproperties of space; it is, as the Aristotelians would say, in potency with regard to space.

The importance of quantum theory from this point of view is that it shows that there are events in the physical world which cannot be represented on the background of space and time. Space and time must accordingly be deposed from the dominant position which they held in Newtonianism. We must begin not with space and time but with events; and the atom, which has a potency of various states, is correlated to the states as potency is to act. It endures as the atom, while it takes different states in succession. Thus, the proton and neutron are now regarded as two 'states' of a single entity, often called a 'heavy particle'. In Aristotelian terms, the heavy particle would be 'matter' and its determinations as a neutron or proton would be its two possible 'forms'. Matter is correlated to form as potency to act.

The peculiarities of modern statistical theory also are conveniently expressible in Aristotelian language. An electron can freely interchange its recognizability with other electrons; it has no sameness of being, no proper identity, no separate history. Its selfhood is merged in an electronhood which it shares with all other electrons, and which is correlated with it as potency to act. This reopens the question which engaged so much attention in the Middle Ages, regarding the nature of universals, or general terms, which represent the common basis of a class of individual objects.

Prof. Whittaker considers that these tendencies of modern physics should lead to more intercourse and mutual understanding between men of science and philosophers; for of all types of philosophy, the Aristotelian-Scholastic is, in its principles, the most congenial to the scientific mind. It is in a sense true that correct, even if in some respects limited, knowledge regarding physics can be combined with any view whatever on the fundamental questions of being and reality, but the effect of such segregated thinking has been to make science a departmental affair, having no influence on life and thought except indirectly through its applications. At the present time there is a movement in scientific circles aiming at securing for science a greater influence on human affairs, and even calling for a refounding of civilization on a scientific basis; but its advocates do not always understand that, as a necessary condition for the possibility of such a reform, science must be reintegrated into a unity with philosophy and religion.

\section{ESKIMO CRANIOLOGY}

$T$ HE first part of a catalogue of human crania in the United States National Museum was issued in 1924. It gave measurements of four short series from parts of Alaska. Since then the Smithsonian Institution has sent eighteen anthropological expeditions to the country, and the United States National Museum now has 2,200 Eskimo skulls, many of which are accompanied by the rest of the skeleton. The latest part of the catalogue to be issued* provides individual measurements of the whole collection of skulls, including a number for which data had been published previously. Dr. Hrdlička, the doyen of American physical anthropologists, has thus made another substantial contribution to the long list of his achievements in collecting, describing and analysing the material of his science.

For each specimen nineteen absolute measurements and twelve measurements of shape (indices and angles)

* Proc. U.S. Nat. Mus., 91, 169-429 (1942). “Catalog of Human Crania in the United States National Museum Collections: Eskimo in General", by Aleš Hrdlicka. (Washington, D.C.: Gov. Printing Office.) 